\title{
The Role of Phosphoinositide Signaling Pathway Components in the Effect of Oxidized Glutathione and Glutoxim on Intracellular $\mathrm{Ca}^{2+}$ Concentration in Macrophages
}

\author{
L. S. Kurilova, Z. I. Krutetskaya, and O. E. Lebedev \\ St.Petersburg State University, St. Petersburg; e-mail: zik@bio.pu.ru
}

DOI: $10.1134 / \mathrm{S} 1990747809030301$

Nowadays the functioning of cellular oxidationreduction (redox) systems and the effect of oxidizing and reducing agents on different cellular processes in normal and pathological conditions are of particular interest. Thus, the pharmacological analogue of oxidized glutathione (GSSG), the drug glutoxim, is used in clinics as a wide range immunomodulator and hemostimulator for integrated treatment of bacterial and viral diseases, psoriases and radio- and chemotherapy in oncology. However, the mechanisms that mediate the regulatory effect of GSSG and glutoxim on cellular processes are still unclear. Previously, we showed for the first time that GSSG and glutoxim increase intracellular $\mathrm{Ca}^{2+}$ concentration, $\left[\mathrm{Ca}^{2+}\right]_{\mathrm{i}}$, due to mobilization of $\mathrm{Ca}^{2+}$ from thapsigargin-sensitive $\mathrm{Ca}^{2+}$ stores and subsequent $\mathrm{Ca}^{2+}$ influx in macrophages. Furthermore, we demonstrated for the first time the involvement of tyrosine kinases, tyrosine phosphatases and phosphatidylinositol kinases in the effect of GSSG and glutoxim on $\left[\mathrm{Ca}^{2+}\right]_{\mathrm{i}}$ in rat peritoneal macrophages.

In peritoneal macrophages, receptors possessing intrinsic tyrosine kinase activity were identified that contained cysteine-rich regions in their extracellular domains, which could serve as targets for GSSG and glutoxim. Activation of these receptor tyrosine kinases could promote the effect of SH2-domain-containing proteins, such as phospholipase $\mathrm{C} \gamma$, cytoplasmic tyrosine kinases of src family and phosphatidylinositol-3 kinase, and trigger the signaling cascade, for example the phosphoinositide signaling pathway. It is known that the key components of phosphoinositide system phospholipase $\mathrm{C}$ and protein kinase $\mathrm{C}$ have a high redox sensitivity and their activities are modulated by oxidizing and reducing agents. Therefore, the purpose of the present research was to study the possible role of the key enzymes of the phosphoinositide signaling pathway, phospholipase $\mathrm{C}$ and protein kinase $\mathrm{C}$, in the regulatory effect of GSSG and glutoxim on $\left[\mathrm{Ca}^{2+}\right]_{i}$ in macrophages. To determine the possible involvement of phospholipase $\mathrm{C}$ in the effect of GSSG and glutoxim on $\left[\mathrm{Ca}^{2+}\right]_{i}$ in rat peritoneal macrophages, we studied the influence of phospholipase $\mathrm{C}$ inhibitor neomycin on $\mathrm{Ca}^{2+}$ response induced by GSSG and glutoxim. To investigate the role of protein kinase $\mathrm{C}$ in the effect of GSSG and glutoxim we used the specific protein kinase $\mathrm{C}$ inhibitors, the compound H-7 and calphostin C.

Macrophage incubation with $100 \mu \mathrm{g} / \mathrm{ml} \mathrm{GSSG}$ or glutoxim for $20 \mathrm{~min}$ led to a significant increase of $\left[\mathrm{Ca}^{2+}\right]_{\mathrm{i}}$ due to $\mathrm{Ca}^{2+}$ mobilization from intracellular stores. The addition of $2 \mathrm{mM} \mathrm{Ca}{ }^{2+}$ to the external medium induced $\mathrm{Ca}^{2+}$ influx caused, apparently, by $\mathrm{Ca}^{2+}$ store depletion. Preliminary incubation of the cells for 10 min with $50 \mu \mathrm{M}$ neomycin completely prevents GSSG- or glutoxim-induced $\left[\mathrm{Ca}^{2+}\right]_{\mathrm{i}}$ increase and $\mathrm{Ca}^{2+}$ influx. Preincubation of the macrophages for $10 \mathrm{~min}$ with $100 \mu \mathrm{M} \mathrm{H}-7$ for $10 \mathrm{~min}$ before $100 \mu \mathrm{g} / \mathrm{ml} \mathrm{GSSG}$ or glutoxim addition also leads to the almost complete inhibition of GSSG- or glutoxim-induced $\left[\mathrm{Ca}^{2+}\right]_{\mathrm{i}}$ increase and prevents $\mathrm{Ca}^{2+}$ influx from the external medium. Similar results were obtained with the use of another protein kinase $\mathrm{C}$ inhibitor calphostin $\mathrm{C}$ in the concentration of $1 \mu \mathrm{M}$.

Thus, we showed for the first time the involvement of the key enzymes of phosphoinositide signaling pathway phospholipase $\mathrm{C}$ and protein kinase $\mathrm{C}$ in the regulatory effect of GSSG and glutoxim on $\left[\mathrm{Ca}^{2+}\right]_{\mathrm{i}}$ in rat peritoneal macrophages. The results obtained in this study, as well as our earlier data, suggest that GSSG and glutoxim transactivate receptors with intrinsic tyrosine kinase activity and trigger a complex signaling cascade, including tyrosine kinases, tyrosine phosphatases, phosphatidylinositol kinases and the key enzymes of phosphoinositide system phospholipase $\mathrm{C}$ and protein kinase $\mathrm{C}$; this leads to increase of $\left[\mathrm{Ca}^{2+}\right]_{\mathrm{i}}$ in macrophages. 